\title{
Hubungan antara riwayat status gizi ibu masa kehamilan dengan pertumbuhan bayi usia $9-12$ bulan
}

\author{
Rilyani*, Lelly Sugiyati
}

Program Studi IImu Keperawatan Fakultas Kedokteran, Universitas Malahayati

*Email: bunda_agungbana@yahoo.com

\section{Abstract \\ Maternal nutritional status during pregnancy and effects on growth among infants 9-12 months}

Background: Maternal nutritional status during pregnancy needs attention because it affects the development of the fetus they are carrying. During pregnancy are at risk of experiencing of chronic energy deficiency (CED) in adults if they have LILA $<23.5 \mathrm{~cm}$ are at risk of maternal death, preterm delivery/low birth weight (LBW), death and impaired growth and development of infant. Base on data in Way Panji Public Health Centre reported that among maternal during pregnancy were of $43(29.05 \%)$ who has LILA $<23.5 \mathrm{~cm}$.

Purpose: To determine the relationship between maternal nutritional status during pregnancy and infant growth at the Way Panji Community Health Centre coverage area

Method: A quantitative by cross-sectional research, the population in this study were of 143 respondent as all maternal who had an infant aged 9-12 months in May 2020. Both of them observed such as a history of maternal nutritional status during pregnancy and infant growth when aged 9-12 months and bivariate analysis (ChiSquare).

Results: Showing that the frequency distribution of maternal nutritional status during pregnancy, mostly with has sufficient in nutrition of $113(79.0 \%)$ respondents and they have an infant with a normal growth of $107(74.8 \%)$. There is a relationship between maternal nutritional status during pregnancy and infant growth ( $p$-value 0.000 : OR 5,314).

Conclusion: There is a relationship between maternal nutritional status during pregnancy and infant growth in Way Panji Public Health Center coverage area Lampung-Indonesia. Suggestions to public health centre management to increase the promotion programme of maternal nutritional status during pregnancy and preventing poor growing of the infant by providing leaflets or posters also supplement nutritions for maternal during pregnancy.

\section{Keywords: Maternal; Nutritional status; Pregnancy; Infant; Growth}

Pendahuluan: Gizi ibu hamil perlu mendapat perhatian karena sangat berpengaruh pada perkembangan janin yang dikandungnya, Wanita hamil berisiko mengalami KEK jika memiliki LILA $<23,5 \mathrm{~cm}$. ibu hamil dengan KEK berisiko melahirkan bayi berat lahir rendah (BBLR). BBLR akan membawa risiko kematian, dan gangguan pertumbuhan dan perkembangan anak. KEK juga dapat menjadi penyebab tidak langsung kematian ibu. Data dari Puskesmas Way Panji mengatakan bahwa terdapat 43 orang $(29,05 \%)$ yang berisiko KEK dengan LILA < $23,5 \mathrm{~cm}$.

Tujuan: Diketahui Hubungan Status Gizi Ibu Masa Kehamilan Dengan Pertumbuhan Bayi Di Puskesmas Way Panji Kecamatan Way Panji Kabupaten Lampung Selatan

Metode: Jenis penelitian kuantitatif dengan menggunakan metode penelitian crossectional, Subyek dalam penelitian ini adalah Ibu Masa Kehamilan, Variabel dependen : Pertumbuhan bayi, variabel independent : gizi ibu saat hamil, populasinya paraibu yang telah melahirkan dan bayinya usia 9-12 bulan dengan total sampel berjumlah 143 responden/bayi, dilakukan pada bulan Juli-Agustus 2020, dengan analisa univariat dan bivariat (Chi-Square).

Hasil: Didapatkan Distribusi frekuensi status gizi ibu masa kehamilan, sebagian besar dengan gizi baik yaitu sebanyak $113(79,0 \%)$ responden. pertumbuhan bayi kategori normal yaitu sebanyak 107 (74,8\%). Ada hubungan status gizi ibu masa kehamilan dengan pertumbuhan bayi ( $p$-value 0.000 : OR 5,314).

Simpulan: Ada hubungan status gizi ibu masa kehamilan dengan pertumbuhan bayi di Puskesmas Way Panji, Disarankan kepadapihak manajemen Puskesmas setempat supaya dapat meningkatan upaya promosi guna 
Hubungan antara riwayat status gizi ibu masa kehamilan dengan pertumbuhan bayi usia 9-12 bulan

penurunan kejadian pertumbuhan bayi yang abnormal dan membantu terpenuhinya kebutuhan gizi atau nutrisi pada saat ibu dalam masa kehamilan dengan cara pemberian leaflet atau poster.

\section{Kata kunci : Riwayat status gizi; Masa kehamilan; Pertumbuhan; Bayi usia 9-12 bulan}

\section{PENDAHULUAN}

Program Kesehatan Ibu dan Anak (KIA) merupakan salah satu prioritas utama pembangunan kesehatan di Indonesia. Program ini bertanggung jawab terhadap pelayanan kesehatan bagi ibu hamil, ibu bersalin dan bayi neonatal. Salah satu tujuan program ini adalah menurunkan kematian dan kejadian sakit pada ibu dan anak melalui peningkatan mutu pelayanan dan menjaga kesinambungan pelayanan kesehatan ibu dan perinatal di tingkat pelayanan dasar dan pelayanan rujukan primer (Saifuddin, 2002).

Angka kematian ibu merupakan salah satu target dalam tujuan pembangunan millenium MDGs 5 yakni menurunkan angka kematian maternal sebesar $3 / 4$ dari angka kematian maternal pada tahun 1999, sebanyak 450 per 100.000 menjadi 102 per 100.000 Kelahiran Hidup pada tahun 2015. Penurunan angka kematian ibu per 100.000 kelahiran bayi hidup masih terlalu lambat untuk mencapai target Tujuan Pembangunan Milenium (Millennium Development Goals/MDGs) (World Health Organization, 2018).

Gizi ibu hamil perlu mendapat perhatian karena sangat berpengaruh pada perkembangan janin yang dikandungnya. Sejak janin sampai anak berumur dua tahun atau 1000 hari pertama kehidupan kecukupan gizi sangat berpengaruh terhadap perkembangan fisik dan kognitif. Kekurangan gizi pada masa ini juga dikaitkan dengan risiko terjadinya penyakit kronis pada usia dewasa, yaitu kegemukan, penyakit jantung dan pembuluh darah, hipertensi, stroke dan diabetes. Pada masa kehamilan gizi ibu hamil harus memenuhi kebutuhan gizi untuk dirinya dan untuk pertumbuhan serta perkembangan janin karena gizi janin tergantung pada gizi ibu dan kebutuhan gizi ibu juga harus tetap terpenuhi (Kementerian Kesehatan Republik Indonesia, 2014). Berdasarkan data dari World Health Organization (WHO), diperkirakan 9,6\% dari semua kelahiran di dunia pada tahun 2015 adalah prematur, yaitu sekitar 12,9 juta kelahiran. Sekitar $85 \%$ terkonsentrasi di Afrika dan Asia, dimana terdapat 10,9 juta kelahiran prematur. Sekitar 0,5 juta kelahiran prematur terjadi di Eropa dan jumlah yang sama terjadi di Amerika Utara, sementara 0,9 juta kasus terjadi di Amerika Latin dan Carribean (Kementerian Kesehatan Republik Indonesia, 2015).

Menurut data Riset Kesehatan Dasar (Riskesdas) Departemen kesehatan di Indonesia sendiri angka kejadian prematur belum dapat dipastikan jumlahnya, namun berdasarkan data Riskesdas tahun 2018, proporsi Bayi lahir rendah (BBLR) mencapai 11,5\%, meskipun angka BBLR tidak mutlak mewakili angka kejadian persalinan prematur (Kementerian Kesehatan Republik Indonesia, 2018).

Salah satu penyebab bayi berat badan lahir rendah (BBLR) adalah lahir kurang bulan (prematur). Jumlah bayi berat lahir rendah (BBLR) di Provinsi Lampung pada tahun 2014 sebanyak 21.184 meningkat banyak apabila dibandingkan tahun 2015 yang sebanyak 15.631. Adapun persentase BBLR tahun 2016 sebesar 3,73\%, meningkat bila dibandingkan tahun 2015 sebesar 2,69\% (Dinas Kesehatan Provinsi Lampung, 2017). Kenaikan berat badan dapat dipakai sebagai indeks untuk menentukan status gizi wanita hamil (Lubis, Mutahar, Fajar, 2013).

Asupan energy dan protein yang tidak mencukupi pada ibu hamil dapat menyebabkan Kurang Energi Kronis (KEK). Wanita hamil berisiko mengalami KEK jika memiliki LILA $<23,5 \mathrm{~cm}$. ibu hamil dengan KEK berisiko melahirkan bayi berat lahir rendah (BBLR). BBLR akan membawa risiko kematian, dan gangguan pertumbuhan dan perkembangan anak. KEK juga dapat menjadi penyebab tidak langsung kematian ibu. Hasil (Kementerian Kesehatan Republik Indonesia, 2004). mendapatkan proporsi ibu hamil umur $15-49$ tahun dengan LILA $<23,5 \mathrm{~cm}$ atau beresiko KEK di Indonesia sebesar 24,2 persen. Hasil Riskesdas 2013, Proporsi ibu hamil dengan LILA $<23,5 \mathrm{~cm}$ menurut provinsi tahun 2013, Provinsi Sulawesi Selatan berada pada peringkat kelima dengan persentase LILA $<23,5 \mathrm{~cm}$ pada ibu hamil sebesar $31,2 \%$, yang kemudian disusul oleh Sulawesi Tengah (32,6\%), Maluku (34,3\%), Papua $(37,2 \%)$ dan NTT $(45,5 \%)$ (Kementerian Kesehatan Republik Indonesia, 2014). 
Hubungan antara riwayat status gizi ibu masa kehamilan dengan pertumbuhan bayi usia 9-12 bulan

Hasil Riskesdas (2018) didapatkan proporsi ibu hamil umur 15-49 tahun dengan LILA $<23,5 \mathrm{~cm}$ atau berisiko KEK di Indonesia sebesar $24,4 \%$. Kemenkes menetapkan kebijakan bila Prevalensi KEK $\geq 10 \%$ merupakan masalah kesehatan masyarakat (Kementerian Kesehatan Republik Indonesia, 2017). Prevalensi lbu hamil KEK berdasarkan data profil Dinkes Provinsi Lampung pada tahun 2016 adalah sebesar 14,86\% meningkat dibanding tahun 2016 sebesar 14,41\%, tertinggi di Kota Bandar Lampung $(22,69 \%)$ dan paling rendah di Kabupaten Lampung Selatan $(11,72 \%)$ (Dinas Kesehatan Provinsi Lampung, 2017).

(Dinas Kesehatan Kabupaten Lampung Selatan, 2019). mendapatkan bahwa proporsi ibu hamil berumur $15-49$ tahun dengan LILA $<23,5 \mathrm{~cm}$ atau berisiko KEK di Lampung Selatan sebesar $22,6 \%$. Prevalensi ibu hamil yang menderita KEK di Lampung Selatan pada tahun 2018 adalah 9,11\%, berbeda dengan Lampung Tengah yang hanya mencapai $15 \%$. Permasalahan ibu hamil KEK merupakan permasalahan mendasar yang perlu mendapat penanganan yang lebih baik, mengingat status kesehatan ibu hamil menentukan dalam menurunkan AKI dan AKB (Dinas Kesehatan Kabupaten Lampung Selatan, 2018).

Berdasarkan hasil penelitian sebelumnya oleh Astrid Purna Dewi Fakultas ilmu kedokteran dengan judul Hubungan kenaikan berat badan ibu hamil dengan berat bayi lahir di RSUD Dr. Moewardi pada tahun 2020 mengatakan bahwa berdasarkan 85 responden terdapat kenaikan berat badan ibu hamil normal sebanyak 52 responden $(61 \%)$ dan terdapat peningkatan berat badan tidak normal sebanyak 33 responden $(38.8 \%)$ dari hasil berat badan bayi lahir bahwa sebagian besar ibu melahirkan bayi normal (> $2500 \mathrm{gr}$ ) sebanyak 72 responden $(84.7 \%)$ sedangkan ibu yang melahirkan bayi BBRL (> 2500) sebanyak 13 responden (15.3\%). Hasil dalam penelitian ini adanya hubungan antara pertambahan berat badan ibu dengan berat badan bayi baru lahir.

Kurang pengetahuan ibu hamil tentang gizi menyebabkan kurangnya makanan bergizi selama hamil. Salah satu faktor yang mempengaruhi gizi ibu hamil yaitu pengetahuan ibu hamil dan keluarga tentang zat gizi dalam makanan. Perencanaan dan penyusunan makanan kaum ibu atau wanita dewasa mempunyai peranan yang penting. Faktor yang mempengaruhi perencanaan dan penyusunan makanan yang sehat dan seimbang bagi ibu hamil yaitu kemampuan ibu dan keluarga dalam membeli makanan serta pengetahuan tentang gizi (Budiman, Pramono, \& Dewantiningrum, 2011).

Pengetahuan yang dimiliki seorang ibu akan mempengaruhi perilaku ibu termasuk dalam pengambilan keputusan. Ibu dengan gizi yang baik, kemungkinan akan memenuhi kebutuhan gizi yang baik untuk bayinya. Sehingga ibu yang memiliki pengetahuan yang baik meskipun pada awal kehamilannya mengalami mual dan rasa tidak nyaman maka ia akan berupaya untuk memenuhi kebutuhan gizinya dan juga bayinya (IImiani, 2019).

Dari data profil dinas kesehatan Kabupaten Lampung Selatan, pada tahun 2019 persentase BBLR meningkat menjadi $3,02 \%$ dari kelahiran hidup (Dinas kesehatan Lampung Selatan, 2017).

Ibu hamil dengan risiko KEK pada tahun 2019 berdasarkan data profil Puskesmas Way Panji Kecamatan Way Panji Kabupaten Lampung Selatan sebanyak $13,4 \%$. Kecamatan Way Panji merupakan kecamatan tertinggi dengan kejadian KEK pada ibu hamil. Data dari Puskesmas Way Panji mengatakan bahwa dari 247 orang ibu hamil terdapat 43 orang $(29,05 \%)$ yang berisiko KEK dengan LILA $<23,5 \mathrm{~cm}$ (Profil Puskesmas Way Panji, 2019).

Berdasarkan hasil pra survey yang dilakukan oleh peneliti tanggal 18 - 20 April 2020 melalui pengambilan data sekunder dari $10 \mathrm{ibu}, 40 \% \mathrm{ibu}$ yang memiliki status gizi baik dilihat dari LILA yang normal selama trimester akhir masa kehamilan yaitu $\geq 23,5 \mathrm{~cm}$, melahirkan bayi yang berat badannya normal yaitu 2500 gram sampai 4000 gram, dan panjang badan normal yaitu $>48 \mathrm{~cm}$, sedangkan $50 \%$ ibu yang memiliki gizi kurang dilihat dari ukuran LILA selama kehamilan yaitu < $23,5 \mathrm{~cm}$, melahirkan bayi yang berat badannya kurang atau rendah yaitu < 2500 gram dan panjang badan $<48 \mathrm{~cm}$, dan $10 \%$ ibu memiliki gizi kurang dilihat dari ukuran LILA selama kehamilan yaitu < $23,5 \mathrm{~cm}$ melahirkan bayi dengan berat badan normal yaitu 2500 gram sampai 4000 gram.

Berdasarkan permasalahan diatas, penulis tertarik untuk melakukan penelitian dengan judul "Hubungan Status Gizi lbu Masa Kehamilan Dengan Pertumbuhan Bayi Di Puskesmas Way Panji Kecamatan Way Panji Kabupaten Lampung Selatan Tahun 2020". 


\section{METODE PENELITIAN}

Jenis penelitian kuantitatif dengan menggunakan metode penelitian survey, populasi dalam penelitian ini adalah ibu yang memiliki bayi usia 9-12 bulan pada bulan Mei 2020 berjumlah 143 responden. Penelitian ini sudah dilakukan uji laik etik di Universitas Malahayati dengan nomor surat 0489.44.02.406.04.2020 tanggal 12 April 2020 dan untuk melihat status gizi ibu selama hamil dengan melihat catatan medis (Medical Record/KIA) kategori $0=$ KEK $($ Lila $\leq 23,5 \mathrm{Cm}) ; 1=$ Normal $($ Lila $>23,5 \mathrm{~cm})$.

Pertumbuhan bayi dengan melihat Kartu Menuju Sehat (KMS). Kemudian dianalisis dengan uji statistik chisquare.

\section{HASIL}

Tabel 1. Distribusi Karakteristik Responden N = 143

\begin{tabular}{|c|c|c|c|}
\hline Karakteristik & Frekuensi (f) & Presentasi (\%) & $(\mathrm{M} \pm \mathrm{SD})$ \\
\hline Usia Ibu (Tahun) (Rentang 23-35 ) & 143 & 100 & $28.62 \pm 3.427$ \\
\hline \multicolumn{4}{|l|}{ Pekerjaan } \\
\hline Ibu Rumah Tngga & 93 & 65.0 & \\
\hline PNS & 36 & 25.2 & \\
\hline Wiraswasta & 14 & 9.8 & \\
\hline \multicolumn{4}{|l|}{ Pendidikan Terakhir } \\
\hline SD & 56 & 39.2 & \\
\hline SMP & 37 & 25.9 & \\
\hline SMA & 18 & 12.6 & \\
\hline Perguruan Tinggi & 32 & 22.4 & \\
\hline \multicolumn{4}{|l|}{ Paritas } \\
\hline Primipara & 57 & 39.9 & \\
\hline Multipara & 86 & 60.1 & \\
\hline \multicolumn{4}{|l|}{ Pertumbuhan Bayi } \\
\hline Abnormal & 36 & 25.16 & \\
\hline Normal & 107 & 74.84 & \\
\hline \multicolumn{4}{|l|}{ Status Gizi Ibu Hamil } \\
\hline Buruk & 30 & 20.97 & \\
\hline Baik & 113 & 79.03 & \\
\hline
\end{tabular}

Berdasarkan hasil penelitian, diketahui bahwa sebagian besar responden berusia 29 tahun dengan rentang usia (mean) 28.62 tahun \pm 3.427 ., sebanyak $56(39.2 \%)$ responden dengan pendidikan SD, sebanyak $93(65.0 \%)$ responden dengan pekerjaan ibu rumah tangga dan sebanyak $86(60.1 \%)$ responden dengan paritas tidak berisiko. 
Hubungan antara riwayat status gizi ibu masa kehamilan dengan pertumbuhan bayi usia 9-12 bulan

Table 2. Hubungan Status Gizi Ibu Masa Kehamilan Dengan Pertumbuhan Bayi

\begin{tabular}{|c|c|c|c|c|c|c|c|c|}
\hline \multirow{3}{*}{$\begin{array}{l}\text { Status Gizi ibu } \\
\text { Masa Kehamilan }\end{array}$} & \multicolumn{4}{|c|}{ Pertumbuhan Bayi } & \multicolumn{2}{|c|}{ Total } & \multirow{3}{*}{$p$ - value } & \multirow{3}{*}{$\begin{array}{c}\text { OR } \\
\text { Cl } 95 \%\end{array}$} \\
\hline & \multicolumn{2}{|c|}{ Abnormal } & \multicolumn{2}{|c|}{ Normal } & & & & \\
\hline & $\mathrm{n}$ & $\%$ & $\mathrm{n}$ & $\%$ & $\mathrm{~N}$ & $\%$ & & \\
\hline Buruk & 16 & 11.18 & 14 & 9.79 & 30 & 20.97 & 0,000 & 5,314 \\
\hline Baik & 20 & 13.98 & 93 & 65.05 & 113 & 79.03 & & $(2,238-12,61)$ \\
\hline
\end{tabular}

Berdasarkan tabel 2 didapatkan bahwa dari 30 responden dengan status gizi masa kehamilan kategori buruk, sebanyak $16(11.18 \%)$ responden dengan pertumbuhan bayi yang abnormal dan sebanyak $14(9.79 \%)$ responden dengan pertumbuhan bayi nornal. Dari 113 responden dengan status gizi masa kehamilan kaqtegori baikl, sebanyak $20 \quad(13.98 \%)$ responden dengan pertumbuhan bayi kategori abnormal dan sebanyak $93(65.05 \%)$ responden dengan pertumbuhan bayi kategori normal.

Hasil uji statistik diperoleh nilai $p$-value $=0,000$ sehingga $p<a=0,05$, yang berarti ada hubungan yang bermakna antara status gizi ibu masa kehamilan dengan pertumbuhan bayi. Secara statistik nilai $\mathrm{OR}=5.314$ yang berarti responden dengan status gizi yang buruk memiliki resiko sebanyak 5.3 kali lebih besar dengan pertumbuhan bayi yang abnormal jika dibandingkan dengan status gizi kategori baik saat hamil.

\section{PEMBAHASAN}

\section{Status Gizi lbu Masa Kehamilan}

Hasil uji statistik diperoleh nilai $p$-value $=0,000$ sehingga $p<a=0,05$, yang berarti ada hubungan yang bermakna antara status gizi ibu masa kehamilan dengan pertumbuhan bayi. Secara statistik nilai $\mathrm{OR}=5.314$ yang berarti responden dengan status gizi tidak normal memiliki resiko sebanyak 5.3 kali lebih besar dengan pertumbuhan bayi kurang baik jika dibandingkan dengan status gizi saat hamil normal.

Hasil penelitian ini sesuai teori yang menyatakan bahwa status gizi ibu hamil sangat mempengaruhi pertumbuhan janin yang sedang dikandung. bila status gizi ibu normal pada masa kehamilan maka kemungkinan besar akan melahirkan bayi yang sehat, cukup bulan dengan berat badan normal. kualitas bayi yang dilahirkan sangat tergantung pada keadaan gizi ibu selama hamil (Fikawati ,Wahyuni, \& Syafiq, 2012). Memperhatikan kecukupan gizi sangatlah penting bagi ibu hamil, mulai dari permulaan kehamilan, sampai menjelang persalinan dan menyusui. apabila pada awal kehamilan terjadi malnutrisi, maka akan sangat mempengaruhi perkembangan dan kapasitas embrio dalam rahim untuk mempertahankan hidupnya. nutrisi yang buruk pada masa kehamilan akan mempengaruhi pertumbuhan dan perkembangan janin dalam kandungan. usia kehamilan sangat menentukan kebutuhan gizi yang akan diperlukan, apabila sedikit saja dari kebutuhan gizi tersebut tidak tercukupi dengan baik, maka akan berdampak tidak baik pada kehamilan ibu maupun pada bayi yang dikandungnya (Paath \& Rumdasih, 2004).

Penelitian Indrawati \& Suratini (2015) hubungan status gizi ibu hamil dengan kejadian pertumbuhan bayi di wilayah puskesmas minggir kabupaten sleman. hasil uji chi square menunjukkan adanya hubungan yang bermakna antara status gizi ibu hamil dengan kejadian pertumbuhan bayi di puskesmas minggir. hubungannya sebesar 0.000 , yang berarti $p<0,05$ maka dapat disimpulkan bahwa terdapat hubungan antara status gizi ibu hamil dengan kejadian pertumbuhan bayi di puskesmas minggir sleman. Penelitian Turhayati 2006) hubungan antara pertambahan berat badan ibu hamil dengan berat badan lahir bayi di kabupaten semarang.. hasil persamaan regresi linier pada uji anova didapatkan nilai $p=0,000$. nilai adjusted $r$ square pada model summary didapatkan hasil 0,111 yang berarti persamaan yang diperoleh mampu menjelaskan berat badan lahir bayi sebesar $11,1 \%$. sebesar $88,9 \%$ sisanya, dijelaskan oleh variabel lain yang tidak diteliti. penelitian ini didukung dengan penelitian ayu rahma \& al muqsith (2015) tentang hubungan lila ibu hamil dengan bb lahir bayi di rsu cut meutia kabupaten aceh utara dan rs tk iv im.07.01 Ihokseumawe diperoleh bahwa ada hubungan antara lila ibu hamil dengan bb lahir bayi dengan $p$ value $=0.006$ 
Hubungan antara riwayat status gizi ibu masa kehamilan dengan pertumbuhan bayi usia 9-12 bulan

Berdasarkan hasil penelitian diketahui bahwa dari dari 30 responden dengan status gizi masa kehamilan tidak normal, sebanyak $14(46,7 \%)$ responden dengan pertumbuhan bayi baik. Menurut peneliti keadaan ibu selama hamil dengan status gizi kurang baik tidak memberikan selalu efek buruk pada bayi setelah dilahirkan, karena kembali pada asupan bayi setelah lahir akan sangat membantu bayi memiliki peningkatan berat badan bayi secara normal.

Seorang ibu yang sering melahirkan memiliki resiko mengalami kurang zat gizi pada kehamilan berikutnya bila tidak memperhatikan kebutuhan nutrisi. Karena selama kehamilan zat gizi akan terbagi untuk ibu serta janin yang dikandungnya. Kemungkinan hidup seorang bayi secara sederhana dapat dihubungkan dengan status gizi makro ibunya, dengan asumsi bahwa peningkatan intake zat gizi makro akan meningkatkan berat badan ibu, yang pada akhirnya akan meningkatkan pertumbuhan janin, sehingga bayi mempunyai kemungkinan lebih besar untuk lahir hidup.

Dari 113 responden dengan status gizi masa kehamilan normal, sebanyak $20 \quad(17,7 \%)$ responden dengan pertumbuhan bayi kurang baik dan sebanyak $93(82,3 \%)$ responden dengan pertumbuhan bayi baik,hal ini dikarenakan faktor faktor yang mempengaruhi berat badan bayi lahir yang lain yaitu pekerjaan, umur, paritas, jarak kelahiran walaupun memang status gizi merupakan faktor utama yang berkaitan erat dengan berat bayi lahir. kejadian pertumbuhan bayi banyak terjadi karena beberapa faktor, yaitu diantaranya faktor ibu, seperti penyakit, keadaan sosial ekonomi, status gizi, dan gaya hidup. faktor janin seperti kelainan kromosom, radiasi, kehamilan ganda, infeksi. faktor plasenta dan faktor lingkungan (Puspitasari, Anasari \& Pajarsari 2011). sehingga pada penelitian ini, walaupun ibu dengan gizi normal namun dikarenakan adanya faktor lain seperti penyakit infeksi yang diderita anak, kemudian praktik menyusu bayi seperti bayi tidak cukup ASI, genetik atau keturunan dari orang tua pendek dan kecil, yang tidak diambil dalam penelitian ini maka bayi pun ada yang mengalami masalah pada pertumbuhan bayi.

Dari 113 responden dengan status gizi masa kehamilan normal, sebanyak $20 \quad(17,7 \%)$ responden dengan pertumbuhan bayi kurang baik, menurut pendapat peneliti bahwa status gizi ibu hamil tidak selalu akan membuat bayi memiliki perkembangan dan pertumbuhan normal setelah dilahirkan. Beberapa faktor yang mempengaruhi pertumbuhan anak antara lain faktor herediter (tergantung ras, genetik, jenis kelamin dan kelainan bawaan), faktor hormonal (insulin, tiroid, hormon seks dan steroid), faktor lingkungan selama dan sesudah lahir (gizi, trauma, sosioekonomi, iklim, aktivitas fisik, penyakit, dll). (Mahayana, Chundrayetti \&Yulistini 2015).

Menurut peneliti bahwa ibu hamil dengan kondisi status gizi normal dapat juga memiliki bayi dengan berat badan tidak naik sesuai usia nya, dari hasil penelitian dapat terungkap bahwa bayi memiliki penyakit sejak lahir seperti infeksi paruparu, alergi susu sapi serta sulit makan saat bayi sudah berusia 6-12 bulan. Keluhan ibu lebih banyak pada keadaan bayi yang sulit makan saat pemberian PMT dan menyusu berkurang saat sudah diberikan PMT, ada juga bayi dengan penyakit diare, lebih mudah terkena batuk pilek sehingga nafsu makan bayi saat sakit berkurang hal ini menyebabkan naik turun berat badan bayi.

Menurut pendapat peneliti kebutuhan nutrisi sebenarnya bukan hanya ketika ibu mengandung, melainkan ketika siap untuk mengandung sudah harus memperhatikan gizi, makanan dan komposisi nutrisinya secara lengkap, sehingga ketika hamil, maka dari segi fisik sudah siap dan proses kehamilan pun akan berlangsung optimal secara nutrisi. sehingga diharapkan bagi tenaga kesehatan umumnya, bidan khususnya untuk meningkatkan promosi kesehatan tentang gizi seimbang bagi ibu hamil terutama pada keluarga yang akan merencanakan kehamilan. upaya-upaya yang dapat dilakukan untuk mencegah terjadinya kelahiran pertumbuhan bayi maka diperlukan dari pihak tenaga kesehatan untuk melakukan promosi kesehatan melalui pemasangan baliho, penyuluhan baik perorangan maupun kelompok serta dapat melakukan pendidikan kesehatan ibu hamil melalui kelas ibu hamil terutama masalah gizi seimbang selama kehamilan agar terhindar dari pertumbuhan bayi serta meningkatkan promosi kesehatan tentang gizi seimbang bagi ibu hamil terutama pada keluarga yang akan merencanakan kehamilan.

Kebutuhan nutrisi sebenarnya bukan hanya ketika ibu mengandung, melainkan ketika siap untuk mengandung sudah harus memperhatikan gizi, makanan dan komposisi nutrisinya secara lengkap, sehingga ketika hamil, maka dari segi fisik 
Hubungan antara riwayat status gizi ibu masa kehamilan dengan pertumbuhan bayi usia 9-12 bulan

sudah siap dan proses kehamilan pun akan berlangsung optimal secara nutrisi. sehingga diharapkan bagi tenaga kesehatan umumnya, bidan khususnya untuk meningkatkan promosi kesehatan tentang gizi seimbang bagi ibu hamil terutama pada keluarga yang akan merencanakan kehamilan.

\section{SIMPULAN}

Diketahui status gizi ibu masa kehamilan, sebagian besar baik yaitu sebanyak $113(79,0 \%)$ responden. Diketahui kejadian pertumbuhan bayi, sebagian besar baik yaitu sebanyak 107 (74,8\%) responden .Ada hubungan status gizi ibu masa kehamilan dengan pertumbuhan bayi di Puskesmas Way Panji Kecamatan Way Panji Kabupaten Lampung Selatan Tahun 2020 ( $p$-value 0.000 : OR 5,314).

\section{SARAN}

\section{Bagi Puskesmas Way Panji Kecamatan Way Panji Kabupaten Lampung Selatan}

Peningkatan upaya promosi petugas kesehatan dalam penurunan kejadian pertumbuhan bayi yang kurang baik dimana berat badan kurang dari normal dengan cara pemberian leaflet atau poster terkait dengan kebutuhan gizi atau nutrisi pada saat ibu dalam masa kehamilan

Mengajarkan ibu yang memiliki perangkat telepon yang bisa digunakan untuk mencari informasi terkait dengan faktor yang berhubungan dengan pertumbuhan bayi dan kebutuhan nutrisi saat ibu hamil serta dampak jika gizi ibu kurang saat hamil

\section{Bagi lbu}

Hasil penelitian ini dapat digunakan sebagai informasi dan referensi bagi ibu-ibu yang berencana untuk hamil atau kembali hamil untuk lebih dapat mengatur dan mempersiapkan kehamilannya. Meningkatkan pengetahuan dengan mencari informasi baik dari media cetak maupun dari internet yang bisa dicari dari handphone yang digunakan.

\section{DAFTAR PUSTAKA}

Budiman, C., Pramono, B. A., \& Dewantiningrum, J. (2011). Korelasi antara Berat Badan Ibu Hamil dengan Berat Lahir Bayi (Doctoral dissertation, Faculty of Medicine).
Dinas Kesehatan Kabupaten Lampung Selatan.(2018). Data dan Informasi Kesehatan Kabupaten Lampung Selatan

Dinas Kesehatan Kabupaten Lampung Selatan.(2019). Data dan Informasi Kesehatan Kabupaten Lampung Selatan.

Dinas Kesehatan Lampung Selatan. (2017). Profil kesehatan Lampung Selatan tahun 2016. Provinsi Lampung

Dinas Kesehatan Provinsi Lampung. (2017). Data Bayi Berat Lahir Rendah. Lampung: Dinas Kesehatan Lampung tahun 2016

Fikawati, S., Wahyuni, D., Syafiq, A., \& Kajian, P. (2012). Status gizi ibu hamil dan berat lahir bayi pada kelompok vegetarian. Makara kesehatan, 16(1), 29-35.

IImiani, T. K. (2019). Hubungan pengetahuan gizi ibu hamil terhadap peningkatan berat badan selama kehamilan di Puskesmas Bandar Lampung.

Indrawati, S., \& Suratini, S. (2015). Hubungan Status Gizi lbu Hamil dengan Kejadian BBLR di Wilayah Puskesmas Minggir Kabupaten Sleman (Doctoral dissertation, STIKES'Aisyiyah Yogyakarta).

Kementerian Kesehatan Republik Indonesia. (2014). Panduan gizi seimbang. Jakarta. Kemenkes RI. Diakses dari: https://www.academia.edu/25314413/Pedoman _Gizi_Seimbang_oleh_kemenkes

Kementerian Kesehatan Republik Indonesia. (2015). Data dan Informasi Tahun 2014 (Profil Kesehatan). Jakarta.

Kementerian Kesehatan Republik Indonesia. (2004). Sistem Kesehatan Nasional. Diakses dari:

https://peraturan.bkpm.go.id/jdih/userfiles/batan g/KEPMENKES_131_2004.pdf 
Hubungan antara riwayat status gizi ibu masa kehamilan dengan pertumbuhan bayi usia 9-12 bulan

Kementerian Kesehatan Republik Indonesia. (2018). Riskesdas: angka kejadian 10 penyakit di indonesia. French. Retrieved from http://www.who.int/about/licensing/\%5Cnhttp://a pps.who.int/iris/bitstream/10665/204871/1/9789 241565257_eng.pdf

Lubis, D. H., Mutahar, R., \& Fajar, N. A. (2013). Hubungan Status Gizi (Pertambahan Berat Badan Ibu Selama Kehamilan dan Ukuran Lingkar Lengan Atas) dengan Berat Badan Bayi Lahir di Kecamatan Indralaya Utara. Jurnal IImu Kesehatan Masyarakat, 4(01), 33-38.

Mahayana, S. A. S., Chundrayetti, E., \& Yulistini, Y. (2015). Faktor Risiko yang Berpengaruh terhadap Kejadian Berat Badan Lahir Rendah di RSUP Dr. M. Djamil Padang. Jurnal Kesehatan Andalas, 4(3).dan

Paath, E. F., \& Rumdasih, H. (2004). Gizi dalam kesehatan reproduksi. Jakarta: EGC.
Puspitasari, C., Anasari, T., \& Fajarsari, D. (2011). Hubungan Antara Kenaikan Berat Badan Selama Kehamilan Dengan Berat Bayi Baru Lahir Di Wilayah Kerja Puskesmas Rawalo Kabupaten Banyumas Tahun 2009-2010. Bidan Prada: Jurnal Publikasi Kebidanan Akbid YLPP Purwokerto, 2(01).

Saifuddin, A. B. (Ed.). (2002 praktis pelayanan kesehatan maternal dan neonatal. Y). Buku panduan ayasan Bina Pustaka Sarwono Prawiroharjo.

Turhayati, E. R. (2006). Hubungan pertambahan berat badan selama kehamilan dengan berat lahir bayi di Sukaraja Bogor Tahun 2001-2003. Kesmas: National Public Health Journal, 1(3), 139-144.

World Health Organization. (2018). 3 in 5 babies are not breastfed in the first hour of life. Diakses dari https://www.who.int/vietnam/news/detail/31-072018-3-in-5-babies-not-breastfed-in-the-firsthour-of-life 